\title{
A richly varied life in physics
}

\section{A Tale of Two Continents: A Physicist's Life in a Turbulent World}

\section{by Abraham Pais}

Princeton University Press: 1997. Pp. 511.

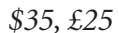

\section{H.B.G.Casimir}

Abraham Pais is a well-known figure among today's senior physicists. In the rather esoteric group of theorists dealing with particles and fields, he ranks as one of the foremost experts, especially on so-called weak interactions. But he is also an expert in a broader sense, as is borne out by his book Inward Bound: Of Matter and Forces in the Physical World (Oxford University Press, 1986). This was preceded by "Subtle is the Lord"(OUP, 1982), a widely acclaimed biography of Albert Einstein, and was followed by the biography Niels Bohr's Times: In Physics, Philosophy and Polity (OUP, 1991).

No wonder Pais has been much in demand as a speaker and often called on to help organize scientific meetings. Prospective readers of his autobiography will therefore expect a richly varied story. They will not be disappointed.

In trying to give an idea of the rich contents, I shall not follow strict chronological order (neither does Pais). But five periods of his life can be distinguished: his youth until the end of the Second World War and of the occupation of the Netherlands (1918-45); a brief stay in Copenhagen (1946); a career at the Institute for Advanced Study in Princeton (1946-63); a professorship at Rockefeller University in New York (1963-88); and his emeritus professorship, with a desk in New York and another in Copenhagen (from 1988 onwards).

The beginnings of the first period were uneventful. Abraham - Bram to his friends - is the son of a Jewish schoolteacher father, belonging to the Portuguese-Jewish (or Sephardic) community, whose ancestors settled in Amsterdam centuries ago. His mother was a teacher as well and, although the family was not wealthy, it managed to get by. Bram was a bright pupil, achieving high grades with little effort. While at home he adhered to the Jewish rites. He soon lost his faith, but became interested in Zionism. Then came the war, Germany's occupation of the Netherlands and the regime's stringent anti-Jewish measures.

Pais just managed to obtain his doctorate before going into hiding. He was found but escaped by the skin of his teeth, thanks to the help of a plucky young woman who, armed with a letter from the German Nobel laureate Werner Heisenberg, went to plead with a high-ranking Nazi official. All this took place against the background of an ever worsening famine. Bram's parents escaped too. His only sister and her husband refused to look for a hiding place, were deported and did not return. The same fate befell George Uhlenbeck's former assistant, Boris Kahn.

Throughout his period in hiding, Pais continued to do theoretical work, some of which was later published. As far as I know, it had no lasting influence, but it must have been a great help in keeping up his morale. One cannot but admire the way in which the young Pais kept up his spirits and how he now writes about his experience.

After the war, Pais's stay in Copenhagen lasted less than a year, during which he acted as a kind of private secretary to Niels Bohr, helping to prepare lectures. The friendships that Pais established in Denmark were confirmed and extended on many later visits.

Pais writes of Bohr: "No other physicist, for that matter no one else, ever has stirred in me feelings of such high respect and deep affection. He is my father figure. Only later did I come to understand how fortunate I have been to spend a period with Bohr that was neither too short nor too long. Why not too long? Because it can be dangerous for a young man in his formative years to spend too much time in the presence of a personality as powerful as Bohr's." However that may be, if Pais, following Einstein, ever had any misgivings about the interpretation of quantum mechanics, they disappeared. $\mathrm{He}$ became a staunch supporter of Bohr's ideas on phenomena and complementarity.

In the autumn of 1946, Pais travelled to the United States and settled in Princeton. Not everyone will agree with his views on the American way of life, but his stories are amusing.

At the Institute for Advanced Study he rose through the ranks, becoming finally a full professor with tenure. Why then did he choose in 1963 to move to New York? He states as his reason that he was afraid of becoming more and more of a manager rather than a scientist. At that time, however, his best work in theoretical physics had been done. At Rockefeller University we see him change gradually into a historian of science.

As to his personal life, Pais has married three times. His first marriage lasted from 1956 to 1962 . He is reticent but unembittered about the separation and writes with true affection about his son, born in 1958, and about his daughter-in-law and grandson. He is rather sarcastic about his second marriage which lasted from 1976 to 1985 : "her running off was the best thing she had ever done for me". Finally, in 1990, he finds the ideal partner, about whom he writes with loving praise verging on adulation.

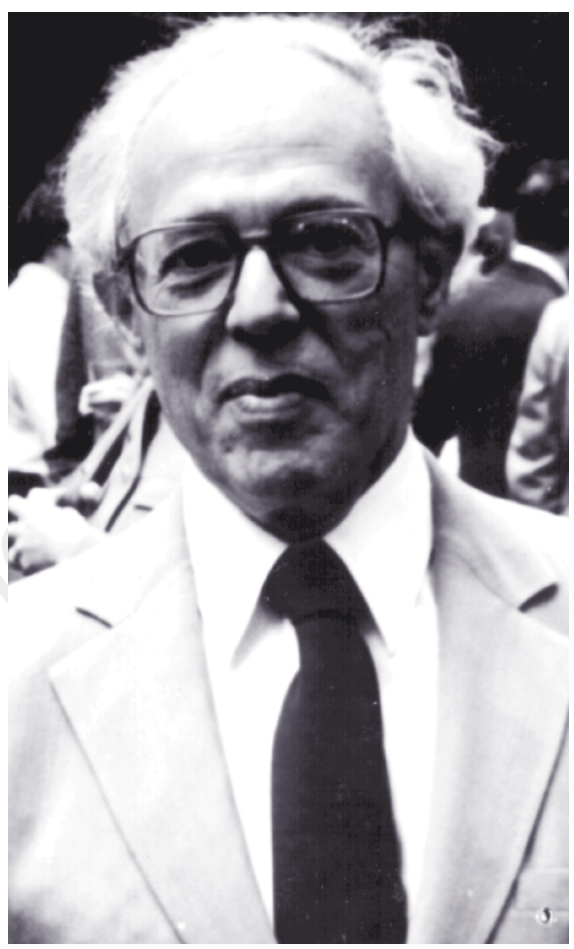

Pais: theoretical physicist turned historian.

Pais has done an enormous amount of travelling, as a tourist, as a visiting scientist and, more often, as a combination of the two. His trips have often involved mountaineering: in 1960 he climbed Mont Blanc, and in 1962 the Matterhorn. With modern equipment and fixed ropes, these climbs are less difficult and dangerous than they were a century ago in the days of the pioneering mountaineer Edward Whymper. But both are strenuous and a remarkable feat for any amateur over 40 .

Scattered through the text are many anecdotes and incisive remarks about famous scientists. There are also sections on world affairs - where, much to my surprise, Pais mentions the World Series baseball championship - and on the art of writing a book.

But it is obvious that Pais, for all his multifarious interests and abilities, is, or was, primarily a hardworking and enthusiastic theoretical physicist. Time and time again he mentions the problems he has worked on and recalls his students and colleagues. He started out with problems in quantum electrodynamics, which was then reaching the stage at which experimental results could be predicted with surprising accuracy, although Pais never found the theory entirely satisfactory.

The bulk of his work deals with particle physics - an entirely new branch of physics with little contact with or influence on the physics of the first half of our century. Pais 
endeavours to explain at least the gist of its development, a development to which he himself made important contributions. Has he succeeded? I am not sure. That the treatment of the mathematics is rather sketchy does not matter for the professional physicist: one can always turn to Inward Bound and, if one wants to become a real expert, from there to one of several good textbooks. But has Pais given nonphysicists an inkling of the reaction of physicists to the sensational news of charge parity violation? Can he convince authorities that it is worth spending thousands of millions to create a few extremely short-lived particles? Perhaps that is asking too much.

No book is perfect. Although Pais is on the whole very readable and both instructive and entertaining, he is sometimes a bit long-winded. Several sections, in particular those dealing with travel, could do with pruning, and some duplication might have been avoided. Pais himself recommends an index of subjects, but does not follow his own advice. But these minor shortcomings in no way detract from the value of this impressive book.

H. B. G. Casimir is at De Zegge 7, 5591 TT Heeze, The Netherlands.

\section{Our flexible friends}

\section{Cells, Embryos and Evolution: Towards a Cellular and Developmental Understanding of Phenotypic Variation and Evolutionary Adaptability}

by John Gerhart and Marc Kirschner

Blackwell Science: 1997. Pp. 642.

$\mathfrak{£} 29.50, \$ 64.95$

\section{J.M.W.Slack}

Every biologist has heard of Darwin's finches and knows that the shape of the beak may evolve differently depending on the food source. But how many ways are there to change a beak? Is the range of possible beaks limited by developmental constraints? Are modern birds better at changing their beaks than their remote forebears? These questions are posed in the preface to Cells, Embryos and Evolution to emphasize that now is the time to apply our newly found molecular understanding of development to find out what really happened in evolution.

John Gerhart and Marc Kirschner are distinguished experts in cell and developmental biology. As might be expected, they paint a mighty canvas and fill it with good things. Much of their text is devoted to a detailed explanation of the main developmental processes in vertebrates and insects, rather less to some important themes in cell biology, and several chapters to an investigation of how the organization of developmental systems has facilitated

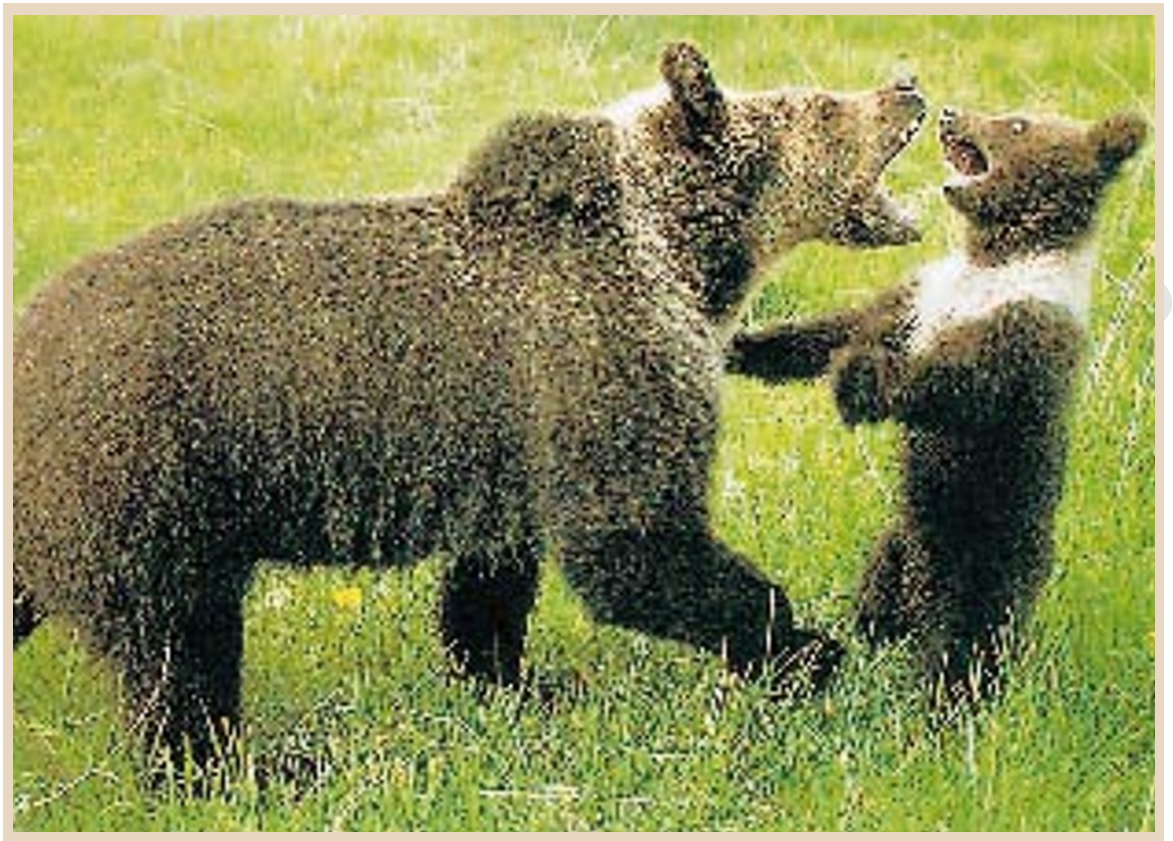

\section{Bear essentials}

Conventional wisdom says you should never come between a mother bear and her cubs. Inadvertently, Erwin A. Bauer did just that when he fell asleep on a hiking trail in Grand Teton National Park in Wyoming. But the bears ignored him and he survived to recount the tale in the introduction to his book, Bears: Behavior, Ecology, Conservation (Voyageur Press, \$35).

the evolution of morphological novelty.

Their grand theme is that the developmental systems of metazoa show "flexibility and robustness", characteristics that may enable mutations to produce significant changes in morphology without always being disadvantageous. The elements of such a system are things such as parallel pathways, weak rather than strong regulatory connections, or competitive and exploratory mechanisms rather than fully determined ones. There may be a progressive increase in 'evolvability' of this kind over evolutionary time. There is no doubt that the developmental mechanisms of vertebrates and insects, which are the two best understood animal groups, show these features, albeit in rather different ways.

But, if we are to ascribe their success in producing many varied morphologies to such characteristics, then we must ask whether other groups that have failed to produce such variety have a developmental system that is demonstrably more rigid. This could possibly be argued of the nematodes, whose morphological diversity as a phylum does not seem to match that of the arthropods or chordates. Early studies of Caenorhabditis elegans did emphasize its rigid cell lineage, but the more the nematode has been studied the less 'hard wiring' of events has been evident and the more signalling processes have been discovered, which would count as "flexible" to Gerhart and Kirschner.
This is the latest in a series of popular books from Voyageur exploring the world of North American bears. In the above picture, one of many fine photos in the book by Erwin and Peggy Bauer, a mother grizzly disciplines a surprised cub that has been wandering too far away. The author gives tips for capturing these elusive creatures on film.

Things are even less clear when we encounter the 'priapulid problem'. The priapulids, named after the eponymous Priapus with his large male generative organ, are an entire phylum containing only 17 species that seem to have changed hardly at all since their appearance in the Middle Cambrian. We have no idea whether they have stayed the same because their developmental systems are inherently less evolvable than more glamorous phyla, or whether there has simply been little selective pressure for diversification because conditions down in the marine mud have not changed much in the past 530 million years.

The book tends to play down the importance of 'constraints', which are the usual concern of developmental biologists. It was at one time supposed that changing almost anything in early development would be impossible because of the knock-on effects on later stages. But this view has tended to moderate as people have become more familiar with the wide range of early adaptations to different reproductive lifestyles. It is now recognized that the stage of maximum similarity between members of a taxon is not the earliest embryonic stage, but the middle stage. This is often called the 'phylotypic' stage, and receives many mentions in the book. But the authors are a little coy about committing themselves to the existence of any phylotypic stages other than the familiar pharyngula of the vertebrates and extended germ band of the insects. 